\title{
The Role of Relational Reward Benefits for Developing the Non-Financial Value of a Customer to an Organization: Structural Equation Modeling Approach
}

\author{
Enny Kristiani, ${ }^{1 *}$ Ujang Sumarwan, ${ }^{1}$ Lilik Noor Yuliati, and Asep Saefuddin ${ }^{2}$ \\ ${ }^{1}$ Graduate School of Management and Business, Bogor Agricultural University (IPB), Indonesia \\ ${ }^{2}$ Department of Statistics, Bogor Agricultural University (IPB), Indonesia
}

\begin{abstract}
Research on the customer value to an organization has been widely explored, yet most studies only determined on the financial value based on the customer's purchasing behavior. The value of customers beyond their purchasing behavior -defined as the relational worth - has not been commonly captured yet. This non-financial value is one of the drivers in retaining customers, hence it becomes a crucial factor in preserving the profitability of the organization. For this reason, this paper aims to examine the customer non-financial valuations of a loyalty reward program. The scope of the study covered a reward program involving consumer exertions in the context of a Frequent Flyer Program (FFP) offered by an airline in Indonesia. The hypotheses are empirically tested with a sample of FFP members conducted through an online survey $(\mathrm{n}=475)$. The data were statistically analyzed using structural equation modeling (SEM) as a first order construct. Results indicate that the perceived social rewards lead to an affective and normative commitment as well as consumers' satisfaction, while the economic reward did not have an effect on developing affective bonds with members for long-term relationships. The relational benefit offered through the FFP creates affectively and normatively committed members who produce relational behaviors, in terms of WOM, immunity, openness and acquiescence of the members to the airline. Furthermore, the FFP members produced social behaviors toward the airline when they felt satisfied with their relational exchanges.
\end{abstract}

\begin{abstract}
Abstrak: Pada umumnya penelitian untuk mengidentifikasi siapa pelanggan-pelanggan yang berharga hanya berasarkan pada nilai transaksi (berapa banyak uang yang dibelanjakan pelanggan) dan belum mempertimbangkan nilai-nilai sosial pelanggan yang diberikan kepada perusahaan. Nilai sosial ini merupakan salah satu penentu keuntungan perusahaan. Penelitian ini bertujuan untuk mengetahui pengaruh hadiah yang diberikan kepada pelanggan terhadap nilai sosial yang dihasilkan. Penelitian dilakukan terhadap program loyalitas yang melibatkan usaha pelanggan dalam mendapatkan hadiah dan dalam konteks Frequent Flyer Program. Hipotesa diuji dengan menggunakan sampel yang terdiri dari 475 anggota FFP yang diperoleh dengan melalui survey online. Data dianalisis secara statistik dengan Stuctural Equation Modelling (SEM). Hasil penelitian menunjukkan bahwa hadiah yang bersifat sosial mempunyai pengaruh signifikan terhadap terciptanya perasaan emosional dan kepatuhan terhadap peraturan atau norma, dan perasaan puas dari
\end{abstract}

* Corresponding author's e-mail: enny.kristiani@yahoo.com

ISSN: $1141-1128$

http://www.gamaijb.mmugm.ac.id/ 
konsumen. Sedangkan hadiah yang bersifatekonomis (monetary) tidak mempunyai pengaruh pada konsumen dalam membangun ikatan dengan perusahaan. Hadiah yang ditawarkan melalui FFP membuat pelanggan menciptakan nilai sosial dalam bentuk: WOM, immunity, openness, acquiescence.

Keywords: frequent flyer program; relational benefits; relational worth

\section{Introduction}

A relational program is a tool for an organization to retain profitable customers and to build customer loyalty by offering incentives (Rust et al. 2000). Reward has proven to strongly affect customers' decision making, and also change their behavior as well. A relational program involves interactive communications and developing a relationship between the customer and the organization. This concept has been widely implemented in many business areas including in the airline industry. Initiating by American Airlines with its frequent flyer program (FFP) known as "Advantage" in 1981, FFPs have become the largest loyalty reward programs with more than 120 million members enrolled in one or more of the 200 FFPs globally (McCaughey and Behrens 2011).

However, in spite of their increasing popularity in many industries, the effectiveness of relational programs has been questionable. Past research by Dowling and Uncles (1997) has even cast doubt on the effectiveness of these relational programs for the patronage of loyal customers. Loyalty programs have also been criticized for their high costs and lack of success in increasing the customer's loyalty time (Rust et al. 2000; Bendapudi and Berry 1997). How do the programs produce beneficial outcomes for the organization? Moreover, very few studies had empirically explored the relational program to explain what the relationship between the relational program and the marketing outcome is, how the relational program develops the expected relationship outcome, and what is the contribution of social benefits to the relationship outcome (Phillips 2007).

In the context of customer equity, consumers generate value to the organization by means of their financial and non-financial contributions. The Customer Lifetime Value (CLV) approach is typically defined as a customer value based on the nominal profit generated by the customer. Therefore, the traditional model of CLV only captures the financial value of the customer to the organization (Reinartz and Kumar 2000). The other value, the non-financial or relational value which refers to the relationship worth in the business-to-customer context, has not been commonly captured yet. The current CLV scheme has not yet accounted for the value of customers beyond their purchasing behavior and this could mislead an organization in loosing valuable customers because of its targeting efforts (Bolton et al. 2004). Customer equity is believed to be driven by the customer lifetime value, the brand and relationship equities across all of the consumers (Rust et al. 2000). The key sub-drivers of relationship equity are loyalty programs, special recognition and treatment programs, affinity programs, community building programs, and knowledge building programs. The context of the relationship is when the company and customers establish and maintain a quality relationship with each other. The re- 
lationship equity is one of the indicators of loyalty but also serves as a predictor for the overall financial health of the company in which incoming revenues can be forecast (Bolton et al. 2004).

The value of a customer to a firm should not only be determined based on profit related matters but also on social interactions which can generate significant future profits for the firm (Hogan et al. 2003). A customer can also add value to the firm through indirect means in which customers voluntary contribute to performing the organization' responsibilities, such as: helping the firm to attract other customers, to retain some current customers, and also to provide guidance to the firm (Phillips 2007). The non-financial behaviors include voluntary partnership activities by the customer by means of spreading word-of-mouth (WOM) information or opinions about the company, making business referrals, giving references and publicity, and offering information and feedback to the organization (Bowen and Shoemaker 2003).

The primary goal of a FFP is to retain a base of committed customers who are most likely to contribute to the profitability of an airline. However most airlines have very little understanding of their FFP members but they do have a little knowledge about their most valuable customers (O'Connel 2009). This fact leads to the question whether the FFP is indeed beneficial for the members as well as for the airline considering the high costs involved in managing the program (Yang and Liu 2003). While FFPs have attracted a great deal of attention in the transportation and marketing literature, there has been no study on the effect of frequent flyer programs on the non-financial worth generated by the members to the airline.
As for the non-financial customer behavior to an organization, the first and only study on the effect of loyalty reward on the non-financial value of the customer to an organization (business-to-customer exchanges) was conducted by Melancon et al. (2011). The study was carried out in a specific geographic area (USA) and on a specific type of relational program (paid and non-accumulated types of reward) in the context of a professional sports team and a fictional hotel reward. Melancon studied this specific paid and non-accumulated reward program, which is similar to many coupon rewards, while our research examines a non-paid and accumulated reward program. The later program involves customer effort to accrue the reward, for instance by accumulating a certain mileage over a set time before being awarded the reward. This role of the customer's exerted effort to obtain the reward and the relational value outcome to the organization has not yet been examined in previous studies. Therefore, this study of the relational worth in terms of the customer's exertion to get the reward is filling a gap in the previous research by Melancon et al. (2011).

Moreover, the effect of satisfaction as a relationship quality on the relational behavior outcome also has not been analyzed. Therefore, the effect of loyalty rewards on the non-financial value in the context of nonpaid and accumulated types of reward, such as airline frequent flyers, has never been studied yet. Hence, the non-financial value of the FFP's members to the airline, related to the loyalty program has not yet been known. The introduction of variable satisfaction in the model of this study fills in the scientific gap of how the customer's effort to obtain rewards could influence the relational outcome in terms of the relational worth between customer and organization. 
For this reason, this paper intends to examine the influence of relational reward benefits on the relationship quality between an organization and its consumers as well as the relational outcomes in terms of the social behavior of the consumers (called "relational worth") to the value of the organization. Referring to Hogan et al. (2003), this research will review the non-financial aspects of customer value to the organization in the context of an aviation loyalty reward program. The current research will also aim to identify the relational worth of the frequent flyer reward.

In line with the above discussion, here are the research questions of the study.

- How does the frequent flyer programs' reward influence the non-financial behavior of FFP members (Relational Worth)?

- How is the relationship quality, customers' commitment to the airline and customer satisfaction, affected by the reward program?

The scope of the study covers the analysis of the nature of a non-paid and accumulated reward program in the context of a FFP offered by an airline in Indonesia.

\section{Hypotheses Development}

The hypotheses developed below are drawn based on our literature review and previous studies. The hypotheses are proposed based the approaches to relational benefit, relationship quality, and relational marketing outcome.

\section{Influence of Reward Type on Customer Commitment}

A relational benefit is a perceived benefit - other than the core service itself - obtained by customers as a result of them hav- ing a long-term relationship with the organization (Hennig-Thorou et al. 2002). Loyalty reward programs consist of two stages: accumulation of points and then redemption. The first stage, points are issued to the consumer in relation to their purchase transactions. In the second stage, the customer receives relational benefits, both social and economic, from the loyalty program (Liu 2008). The dimension of relational benefits, which refers to the Cognitive Evaluation Theory (CET) is described below.

\section{Social Reward Benefit}

Social reward benefit is a non-material reward which increases the internal enjoyment of behavior and the internal reason for maintaining such behavior. Social reward benefits include special and customized attentions and treatments provided to customers, such as participating in exclusive events, better service, and friendly relations between the customer and the company (Berry 1995; and Gwinner et al. 1998). Social benefits have been considered to involve feelings of familiarity, personal recognition, friendship, personal bonding, as well as social support (Barnes 1994; and Berry 1995 in HennigThurau et al. 2002). Based on previous research, FFP' members are indentified as expecting intangible values and services, such as: booking priority and booking guarantee, and a special lounge facility (Weber 2005). Social rewards strengthen the relational exchange between the two parties by developing emotional feeling. Customers feel they are engaging with the organization through their affective commitment and this enhances the value of the transactional behavior (Price and Arnould 1999; and Rust et al. 2000). The social content of the relationship involves feelings of compatibility amongst the involved parties (consumers and organization). 


\section{Economic Reward Benefit}

The economic reward benefit is a monetary related reward in exchange for desired behavior. This economic reward includes financial incentives such as discounts, incentive goods/services, or special price offers with the expectation of increasing loyalty (Berry 1995). The major economic reward benefits for FFP's members are free tickets and upgrading (Hsieh 2007). There is limited emotional bonding occurring in the relationship, so customers often switch to a competitor. Economic reward benefits weaken the relational exchange between the two parties by developing emotional feelings (Deci and Ryan 1985). The customer looks only to get the reward, and has no feelings of enjoyment or interest and no emotional engagement in the relationship itself. Based on its nature, economic reward benefits are expected to weaken the intrinsic motivation because customers attribute their behavior to focusing on getting the reward. Therefore, economic rewards are expected to engage customers through continuance commitment instead of emotional behavior in affective commitment.

Commitment is defined as an individual's motivation to maintain a valued relationship with an organization (Moorman et al. 1992) and the binding of individuals to consistent personal motivations (Morais 2000). The construct of commitment refers to Alen and Meyer' three-component model is described below.

\section{Affective Commitment}

The commitment of an individual to stay with the providers because of an emotional bond with the organization, and it is indentified with his/her involvement with the organization (Allen and Meyer 1991). A customer with a strong affective commitment will maintain the relationship with the orga- nization. This affective commitment represents an intrinsic commitment of customers to maintain their relationship with the organization because of their feelings of satisfaction and enjoyment interacting with the organization (Melancon et al. 2011). Consequently, those customers who are intrinsically motivated to engage in the relational program will likely develop an emotional bond with the organization.

\section{Normative Commitment}

The commitment of an individual to stay with the providers because of the feeling of obligation, and it is indentified with feeling guilty or unease at leaving the organization (Deci 1980; and Allen and Meyer 1991). The antecedent of normative commitment includes social norms or expectations of commitment to an organization, the cost of training employees, and rewards in advance, and member's interdependence (Allen and Meyer 1990; and Gruen 2000). Affective commitment is also believed to be an antecedent for normative commitment because one requires an emotional feeling first before having any feeling of obligation.

\section{Continuance Commitment}

The continuance commitments focus on the customer's intention to obtain incentives, and to maintain the current level of rewards, or the fear of loosing their investment in the relationship (Meyer and Allen 1991) and relates to the switching cost (Bansal et al. 2004). Continuance commitment represents a reward-focused term, an extrinsic commitment from customers to maintain their relationship with the organization because of their investment in the organization (Melancon et al. 2011). Continuance commitment is expected to develop from the switching costs which represent a loss of investment (rewards, time and money) when leav- 
ing the organization, and a lack of available alternatives (Basal et al. 2004). Continuance commitment represents an extrinsic commitment by customers to maintain the relational program because they have already invested in the organization. Consequently, those customers who are extrinsically motivated to engage in the relational program are unlikely to develop any emotional bond and feeling of enjoyment with the organization. These kinds of customers are likely to develop a bond with the organization which is limited to getting the reward only.

Based on the above concepts of reward type benefits and the three-component model of commitments, the following hypotheses will test whether there is a relationship between the relationship commitment and the benefit of a frequent flyer program.

$H_{i}$ : Perceived social rewards will have a positive relationship with affective commitment

$H_{2}$ : Perceived economic rewards will have a negative relationship with affective commitment

$H_{3}$ : Perceived social rewards will have a negative relationship with continuance commitment

$\mathrm{H}_{4}$ :Perceived economic rewards will have a positive relationship with continuance commitment

\section{Influence of Reward Type on Customer Satisfaction}

Satisfaction is an emotional reaction of consumers to the perceived differences between performance appraisal and expectations (Oliver 1980). On the contextual customer-organization relationship, the non-financial relational benefits are significantly related to the satisfaction with the service provider organization (Gremler and Gwinner 2000; Price and arnould 1999). The benefits received from special treatments such as economic savings or customized services are expected to positively influence the customer's satisfaction with the service provider (Hennig-Thorau 2002). According to Hennig-Thorau and Klee (1997), satisfaction is related to the realization of the customer's social needs which then leads to emotional bonding of the customer to the service provider. Therefore, either social benefits or economic benefits are expected to influence customer satisfaction. The following hypotheses are proposed to test the relationship between satisfaction and reward type benefits.

$\mathrm{H}_{5}$ :Perceived social rewards will have a positive relationship with satisfaction

$H_{6}$ :Perceived economic rewards will have a positive relationship with satisfaction

\section{Influence of Reward Policy on Customer Commitment}

Based on the CET approach, the condition in which the reward is offered or redeemed (reward policy) does also influence the behavior of consumers. A reward policy may increase customer commitment through influencing their perceived autonomy. The condition "controlling" is believed to reduce consumer's self-determination, leading to a reduced intrinsic motivation by the consumer to the offered rewards.

Strict reward policy, related to "controlling signals", is the condition in which the consumer feels as if his or her autonomy or competence is restricted. Determinants of strict reward policy may include high value rewards (Scott 1976), reward restrictions i.e. choice of rewards, regulation of accumulation and redemption, expiration limitations, available seat limitation, blackout dates or other restrictions in many relational programs (Melancon et al. 2011). A flexible reward policy, related to "low controlling signals", is the condition in which the consumer feels they have more freedom in their autonomy. This state affects the customer's intrinsic 
motivation and increases customer commitment. On the other hand, a strict reward policy is believed to reduce consumer's selfdetermination and reduce the intrinsic motivation of the consumer to the offered rewards. In this condition, customers feel their autonomy and competence are being controlled, and engage in extrinsic motivation in order to maintain the reward benefits. Therefore, it is believed that this circumstance will weaken the effect of the customer's affective commitment while increasing the continuance commitment to the organization. The following hypotheses are proposed to test the influences of the reward policy on customer commitment.

$H_{\rightarrow}$ Perceived controlling reward policy will have a negative relationship with affective commitment

$H_{8}$ : Perceived controlling reward policy will have a positive relationship with continuance commitment

\section{Influence of Customer Commitment on Relational Outcome}

Relational worth is considered as a social behavior in a non-monetary concept toward the organization as an outcome from its valued relational exchanges with its customers. This value, in addition to the CLV, was believed to be a key component for organizations to indentify customers who could provide maximum profitability and equity (Bolton et al. 2004; and Hogan et al. 2003). The first scholar who developed the constructs of relational worth for examining customers' non-financial behavior was Melancon et al. (2011), which comprised of word-ofmouth (WOM), immunity, openness, acquiescence and honesty.

\section{Word-of-mouth}

WOM as a social behavior is very valuable to an organization when its customers spread positive reports to people outside the organization, thus performing one of the duties of the organization for free. WOM communication is a powerful tool in influencing other customers in their future buying decisions (Hennig-Thurau et al. 2002). Other scholars have even suggested that WOM is nine times more effective than advertising in influencing customer's attitudes toward the product or service (Day 1971, in Phillips 2007).

Identified WOM antecedents include the consumer's degree of satisfaction or dissatisfaction with their consumption experience (Reichheld and Sasser 1990, in Anderson 1998). Involvement or commitment is also regarded as an antecedent of productrelated word-of-mouth (Dicher 1966; and Richins 1984, in Anderson 1998). Affective commitment also has a significant positive relationship to advocacy intention which is desirable in promoting the organization to friends and family (Fullerton 2003; and Bowen and Shoemaker 2003). HarissonWalker (2001) found a positive effect of affective commitment on WOM. Hence, affective commitment has a significant relationship with the word-of-month spread, while continuance commitment was not related to the word-of-mouth (Harrison Walker 2001). A previous study by Gruen et al. (2000) also did not find any significant impact of continuance commitment on WOM spread. However, some studies found there was a positive relationship on continuance commitment to WOM (Meyer et al. 2002; and Phillips 2007) while both Fullerton (2003) and Bendapudi and Berry (1997) found a negative impact of continuance commitment to WOM.

Normative commitment was also found to have a positive relationship to WOM (Gruen et al. 2000), however another study 
produced an opposite result (Phillips 2007). A more current study by Finn (2005) also supports the above theory of WOM. Maintaining high-quality relationships with customers appears to increase their willingness to provide referrals (Finn 2005). Obtaining referrals is critical to the success of the continued relationship.

\section{Immunity}

Immunity is described as a tendency to remain loyal to the organization and to resist any offers from competitors or negative information about the organization (Bolton et al. 2000). The behavior also causes consumers to ignore poor levels of service and have lower expectations of the organization, whilst still remaining loyal to it (Hess et al. 2003). Hence, immunity is believed to protect organizations against losing customers (Bolton et al. 2000).

The customer who has emotional feelings with the organization will ignore the negative information from competitors with this immunity (Phillips 2007). In the meanwhile, a customer who feels pressurized or controlled in the relationship is likely to pursue any alternatives offered (Bendapudi and Berry 1997). Affective commitment had a positive effect on retaining customers (Fullerton 2003; Bendapudi and Berry 1997; Allen and Meyer 1990). A recent study also supports this relationship (Phillips 2007). The impact of normative commitment on immunity varied, ranging from positively related (Gruen et al. 2000) to weakening immunity (Bansal et al. 2004; Phillips 2007). Continuance commitment would lead to negative immunity behavior (Bansal et al. 2004; Bendapudi and Berry 1997). However other scholars believe that continuance commitment has positively affected the immunity behavior (Fullerton 2003).

\section{Openness}

In the context of relational behavior, the alternative to losing a customer, with no indication of what went wrong in the relationship, is openness (Hirschman 1970). Customers respond to disappointment in two different ways: they either leave the organization ("exit") or stay with the organization and "voice" their complaint. The exit-voice model was introduced by Hirschman (1970). Customers, who are willing to give honest feedback to the organization, help it in carrying out its relationship marketing goals (Morgan and Hunt 1994). Having accurate information from the customers, an organization can adjust its services to meet the customer's preferences.

This voice behavior is very valuable for organizations to do rectification so that the customer can be retained. Morgan and Hunt (1994) termed this voice behavior as "cooperation" meaning that the customer and organization are working together to obtain their objectives. Voice behavior is also related to overall satisfaction. Individuals who feel comfortable and satisfied in their relationship with the organization are likely to share constructive criticism with that organization (Ping 1993). Hence, customers having affective commitment are more likely to demonstrate this openness behavior to the organization because of their belief that the information and complaints they provide to the organization will help the organization rectify the problem and improve the business. A sense of being obligated to the organization would likely impact customers with a normative commitment to openness behavior (Gruen et al. 2000). However, Phillips (2007) found that a normative commitment negatively related to openness but positively related to a continuance commitment. 


\section{Acquiescence}

Acquiescence or flexibility in dealing with the organization refers to the customer's tendency to be cooperative in all their dealings with the organization in order to maintain the relationship with the organization. The dimension of acquiescence is adopted from extant literature, including: flexibility (Ivens 2004), adaptation (Wilson 1995), agreeableness (Morgan and Hunt 1994) and adherence to request (Bendapudi and Berry 1997). Behavior flexibility is defined as an individual's readiness to adapt an existing implicit or explicit agreement to new environmental conditions (Ivens 2004).

In the context of relational behavior, a customer's willingness to comply with, and adopt, the organization's new policy or request, is believed to save the organization time, money, prevent it loosing customers, and service recovery efforts because its customers are ready to react and adapt to unforeseen changes. Individuals with emotional and dedicated based relationships with the organization would likely demonstrate acquiescence behavior (Bendapudi and Berry 1997; Morgan and Hunt 1994; Ivens 2004; and Heidi and John 1992). Individual commitment with a sense of obligation would reveal acquiescence behavior which would not be found in the continuance commitment (Gruen et al. 2000).

\section{Honesty}

Honesty is defined as a display of honesty and good faith in all dealings with the organization and a reluctance to take advantage of the organization in any manner (Melancon et al. 2011). It was revealed based on the literature of opportunism and resistance to opportunism; a lack of opportunism Joshi and Arnold 1997; Williamson 1985 in Melancon at el. 2011). Opportunism is detri- mental to the stability of the relationship. The benefits of opportunism accrue unilaterally and in the short term, while the costs of opportunism accrue bilaterally and over a long term (Joshi and Arnold 1997).

Opportunistic behavior is likely to be found if the relationship is not mutual, that is, in which one party is highly dependent on the other, the relationship is inflexible, and there is a low level of engagement between the parties (Joshi and Arnold 1997). Continuance commitment generated opportunistic behavior in the context of a study of business-to-business (Geykens et al. 1996). Therefore it is believed that continuance commitment may lead to opportunistic behavior. Affective commitment would drive customer likely behaving ethical behavior to organization (Venkehove et al. 2003). The customer tends to reveal more ethical behavior and less opportunistic and self-serving behavior if the customer is emotionally attached to the organization. Meyer et al. (2002) revealed the same, that affective commitment would reduce negative or unethical behavior against the organization. Normative commitment is also likely to reduce opportunistic behavior (Gruen et al. 2000). However, calculative commitment that is similar to continuance commitment was found to be positively related to opportunistic behavior Joshi and Arnold 1997; Geykens et al. 1996; and Phillips 2007).

It is believed that commitment reduces the tendency to leave the relationship with the organization, reduces uncertainty, increases acquiescence and increases the belief that any conflict will be functional (Morgan and Hunt 1994). The behavioral consequences of commitment include voluntary partnership activities by the customer. These partnership actions vary from spreading the WOM, making business referrals, providing 
references and publicity, and providing information and feedback to the organization (Bowen and Shoemaker 2003). Commitment is also found to be a key driver of customer's resistance to change (Iwasaki and Hafidz 1998). An attitude of resistance to change could be viewed as resistance to leave the relationship with the organization or rejection of alternative offers from other organizations. Therefore, it is also believed that the relationship commitment has a relationship with the dimensions of relational worth, such as WOM, immunity, openness, and acquiescence. Hence, the following hypotheses are suggested.

$H_{9}$ : Affective commitment will have a positive relationship with word-of-mouth

$H_{10}$ : Affective commitment will have a positive relationship with immunity

$H_{11}$ : Affective commitment will have a positive relationship with openness

$H_{12}$ : Affective commitment will have a positive relationship with acquiescence

$H_{13}$ : Normative commitment will have a positive relationship with word-of-mouth

$H_{14}$ : Normative commitment will have a positive relationship with immunity

$H_{15}$. Normative commitment will have a positive relationship with openness

$H_{16}$ Normative commitment will have a positive relationship with acquiescence

$H_{1 \rightarrow}$ : Continuance commitment will have a negative relationship with word-of-mouth

$H_{18}$ : Continuance commitment will have a negative relationship with immunity

$H_{19}$ : Continuance commitment will have a negative relationship with openness

$\mathrm{H}_{20}$ : Continuance commitment will have a negative relationship with acquiescence.

\section{Influence of Customer Satisfaction on Relational Outcome}

The relationship between satisfaction and the relational marketing outcome has not yet been examined. However, some studies have suggested the antecedents of relational worth as well as consequences of satisfaction.

It is believed that customer satisfaction is a key element of customer retention through customer loyalty and positive WOM communication (Anderson 1998; Anderson and Sullivan 1993; Fornell 1992; and Hallowell 1996). The impact of a customers' overall level of satisfaction is generally measured by the constructs of their willingness to recommend and what recommendations they make to others (Anderson 1998). Ekinci et al. (2008) identified that customer satisfaction levels included the customers' overall attitude to the firm at the post purchasing point, and if they intended to return. This satisfaction also forms intentions on the side of the customer, including the intention to use (to return), the intention to switch and also the intention to recommend (Caruana 2002). The literature proposed that the outcomes of customer satisfaction are loyalty, retention and the extent to which the customer informs friends and family of their experience with the firm (WOM). Customer retention involves emotional-cognitive behavior by the customer in the form of their willingness to recommend and intention to repurchase.

Accordingly, it seems reasonable to assume that the customer satisfaction of the loyalty reward program is likely to influence the relational worth (WOM, immunity, openness, and acquiescence). 
$H_{21}$ : Satisfaction will have a positive relationship with word-of-mouth

$H_{22}$ : Satisfaction will have a positive relationship with immunity

$H_{23}$ : Satisfaction will have a positive relationship with openness

$H_{24}$ : Satisfaction will have a positive relationship with acquiescence

\section{Framework}

Derived from the above approaches, the model of relational values of FFP members to the organization is developed as framework shown in Figure 1.

In the context of analyzing loyalty reward programs, this research expanded on previous studies on the influence of efforttype programs to customer outcome behavior. Understanding how the customer exerts themselves to get the reward (ie. a non-paid and accumulated reward program) enhancing or undermining customer behavior is a critical area of study. The impact of customer efforts in obtaining the rewards has not been considered in past studies. Furthermore, this study is the first to consider construct satisfaction as a relationship quality contributing a significant relationship to the specific nonfinancial valuation.

This study becomes unique by accessing a direct FFP relationship between the airline and the members to examine the financial value of the FFP members. Research with access to actual FFP data from an airline is still uncommon (McCaughey and Behrens 2011). The result does contribute to the literature on relational reward programs and suggests to the industry in practice how reward benefits influence the quality of the relationship and the relational outcomes should help the industry designing more effective reward programs.

\section{Figure 1. Conceptual Model}

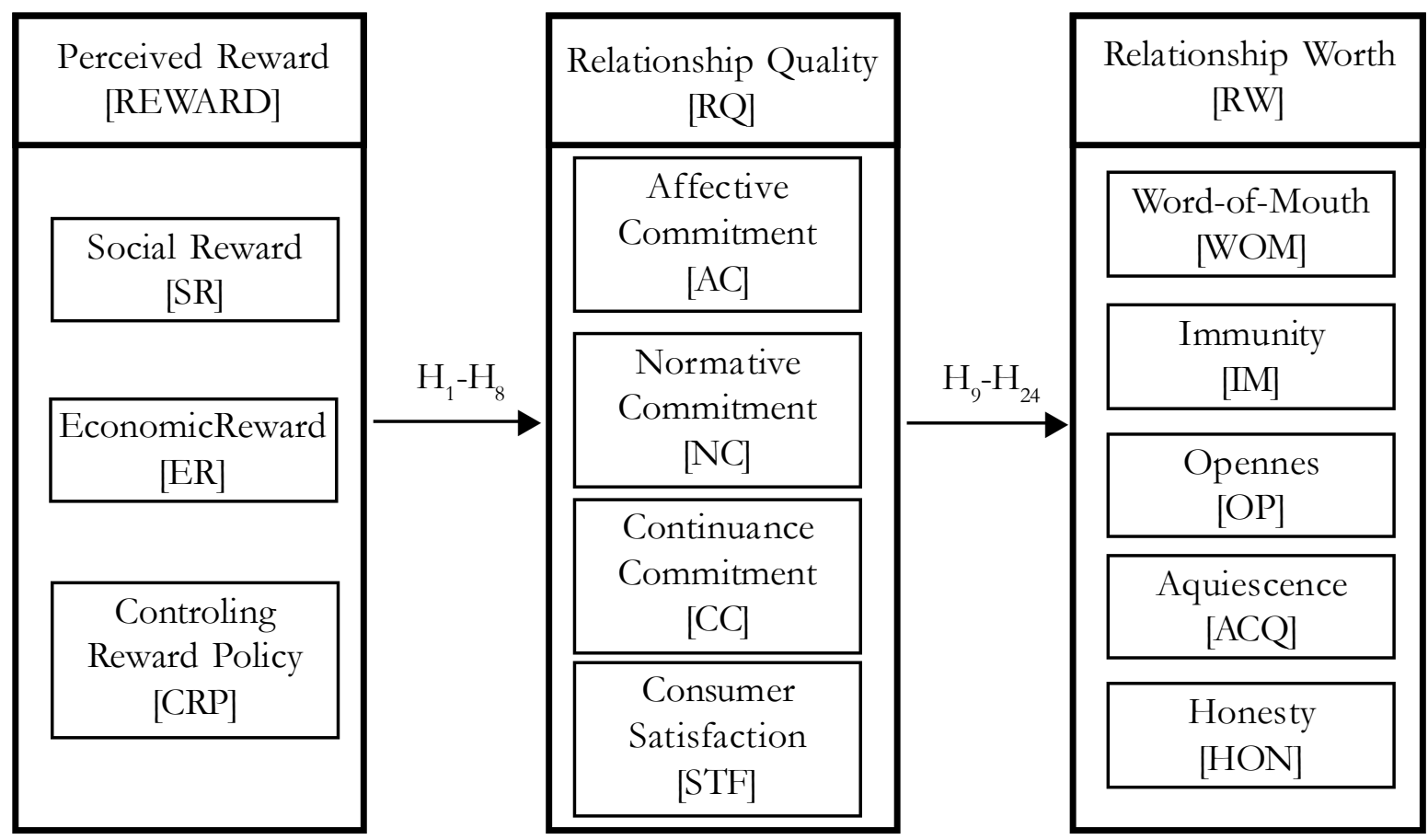


The rest of the paper will be organized as follows, after the introduction, we describe the data and methodology in Section 2, followed by the result and discussion, the summary, conclusions and final remarks in Section 3.

\section{Methods, Variable and Data}

\section{Research Design}

In this study, the FFP of Garuda Indonesia was used to represent the loyalty program of an airline in Indonesia. The analysis to examine the model of the relationship of relational benefits and relational worth used primary data. An online survey was used to test the influence of the FFP's reward benefit on the relationship quality and non-financial behavior of the members. The online survey was conducted by the associated airline through the Garuda Frequent Flyer (GFF)'s system in August 2013. Respondents were invited to participate in the study by sending an initial e-mail letter through the airline's e-blast system which included an embedded URL link to the online survey hosted by the Googledrive engine. A website was constructed containing the three sections of the survey instrument. The first part contained questions about the customers profile, the second part questioned members preferences of the reward benefits, and the third part covered the main questions regarding customer non-financial valuation. Respondents who participated in the study were awarded an incentive of 300 GFF free miles credited to their GFF account.

\section{Sampling Technique}

A sample was taken of the Garuda Frequent Flyer (GFF) members. The sampling technique was a stratified random sampling generated by the system. This stratified sampling was determined based on the tier level. The sample size was 4,900 members of the FFP. A total of 475 respondents returned usable responses. The response rate was 9.69 percent including invalid and bounced emails. This number was deemed to be acceptable based on the constraints of the structural equation modeling. Hair et al. (2010) emphasized that the ratio of free parameters estimated to sample size lie in the range of 10:1 to 5:1. Referring to the recommendation, a minimum sample size of 185 is required for representing 37 questionnaires. In terms of representing the population variance and desired precision, Krejcie and Morgan (1970) recommended an optimum sample size (n) of 384 for the population of GFF members at 0.05 of standard error. Hence, the sample size of 475 in the study is deemed to adequately represent the model.

\section{Variable and Measurement}

The variables and scales used in this study are adapted from previous studies with suitable adjustments to match the context of a FFP. All indicators are measured on a 6point Likert scale where $1=$ strongly disagree, $2=$ disagree, $3=$ mildly disagree, $4=$ mildly agree, $5=$ agree, $6=$ strongly agree. This $6-$ point Likert scale format was employed to avoid neutral answers from the respondents. All the items and scale sources of the study are presented in Table 1. 
Table 1. Variables

\begin{tabular}{cllcc|}
\hline No & \multicolumn{1}{c}{ Latent Variable } & \multicolumn{1}{c}{ Scales } & Items \# & Method \\
\hline 1 & Social Reward Benefit & Modification of Hennig-Thurau et al. (2002) & 4 & Likert 1-6 \\
2 & Economic Reward benefit & Modification of Hennig-Thurau et al. (2002) & 3 & Likert 1-6 \\
3 & Controlling Reward Policy & Modification of Melancon et al. (2011) & 3 & Likert 1-6 \\
4 & Affective Commitment & Meyer \& Allen (1991) & 3 & Likert 1-6 \\
5 & Normative Commitment & Meyer \& Allen (1991) & 4 & Likert 1-6 \\
6 & Continuance Commitment & Meyer \& Allen (1991) & 2 & Likert 1-6 \\
7 & Satisfaction & Modification of Oliver (1980) & 3 & Likert 1-6 \\
8 & WOM & Modification of Anderson (1998) & 3 & Likert 1-6 \\
9 & Openness & Bendapudi \& Berry (1997), Hirschman (1970) & 3 & Likert 1-6 \\
10 & Acquiescence & Ivens (2004), Wilson (1995) & 3 & Likert 1-6 \\
11 & Immunity & Bolton (2000) & 3 & Likert 1-6 \\
12 & Honesty & Joshi \& Arnold (1997) & 3 & Likert 1-6 \\
\hline
\end{tabular}

\section{Hypotheses}

The hypotheses of the research examined the relationship between the perceived rewards and relationship quality, and the relationship quality and relational worth as a first order construct. The hypotheses directions were summarized as follows:

a. Relational benefits will influence relationship quality $\left(\mathrm{H}_{1}-\mathrm{H}_{8}\right.$ testing)

$H_{1}$ Perceived social rewards have a positive relationship with affective commitment

$\mathrm{H}_{2}$ Perceived economic rewards have a negative relationship with affective commitment

$\mathrm{H}_{3}$ Perceived social rewards have a negative relationship with continuance commitment

$\mathrm{H}_{4}$ Perceived economic rewards have a positive relationship with continuance commitment

$\mathrm{H}_{5}$ Perceived social rewards have a positive relationship with satisfaction

$\mathrm{H}_{6}$ Perceived economic rewards have a positive relationship with satisfaction
$H_{7}$ Perceived Reward policies have a negative relationship with affective commitment

$\mathrm{H}_{8}$ Perceived Reward policies have a positive relationship with continuance commitment

b. Relationship quality will influence relational worth $\left(\mathrm{H}_{9}-\mathrm{H}_{24}\right.$ testing)

$\mathrm{H}_{9}$ Affective Commitments have a positive relationship with WOM

$H_{10}$ Affective Commitments have a positive relationship with immunity

$H_{11}$ Affective Commitments have a positive relationship with openness

$H_{12}$ Affective Commitments have a positive relationship with acquiescence

$H_{13}$ Normative Commitments have a positive relationship with WOM

$H_{14}$ Normative Commitments have a positive relationship with immunity

$H_{15}$ Normative Commitments have a positive relationship with openness

$H_{16}$ Normative Commitments have a positive relationship with acquiescence 
$H_{17}$ Continuance Commitments have a negative relationship with $W O M$

$H_{18}$ Continuance Commitments have a negative relationship with immunity

$H_{19}$ Continuance Commitments have a negative relationship with openness

$H_{20}$ Continuance Commitments have a negative relationship with acquiescence

$H_{21}$ Satisfactions have a positive relationship with WOM

$H_{22}$ Satisfactions have a positive relationship with immunity

$H_{23}$ Satisfactions have a positive relationship with openness

$H_{24}$ Satisfactions bave a positive relationship with acquiescence

\section{Data Analysis}

The analysis of the non-financial value of the members to the company was conducted using a two-step approach to SEM (Anderson and Gerbing 1988). The first step consisted of an assessment of the measurement model fit and the second step consisted of analyzing the structural (theoretical) relationship hypothesized within the conceptual model. LISREL version 8.30 was used in this study.

\section{Pre-Test}

A pre-test was conducted on the FFP member samples $(n=30)$ before running the model to provide validation that the questions were read and understood the same way by the respondents. The validity test was done by a Factor Analysis, while the reliability test was conducted by a Cronbach alpha test. All indicators passed the validity test with results of between 0.730-0.968, and the reliability test showed more than 0.7 of
Cronbach alpha, as presented in Appendix 1 and 2.

The results indicated that the validity and reliability of the questionnaire were acceptable. All of the questionnaires were positioned for full release in the online survey to the respondent pool.

\section{Analysis and Discussion}

\section{Descriptive Statistics}

Four hundred and seventy-five members participated in the online survey. The sample distribution of GFF members for this study is dominated by male members $(79 \%)$, Indonesian nationality $(82 \%)$, age between $31-40$ years $(37 \%)$, blue tier $(53 \%)$, graduated from a university or equivalent $(60 \%)$, working as a government official or professional/manager each at 32 percent, and living in Indonesia (82\%).

Most of the respondents have an exclusive FFP membership only with that particular airline (69\%) and preferred flight-related redemptions, free tickets and upgrading $(75 \%)$. The majority of the respondents $(61 \%)$ decided that the award-ticket program was their most preferred redemption program. Referring to the behavioral learning theory, the award-ticket redemption reward has been defined as product reinforcement by fixedratio reinforcement (schedule) from product consumption for its influence on the likelihood of repetition of the response as a consumer behavior (Sumarwan et al. 2011).

\section{Measurement Model Assessment}

The measurement model specifies how the latent variables are measured in terms of the observed variables. It describes the mea- 
surement properties (validities and reliabilities) of the observed variables. This includes the determination of the construct validity of each of the scales presented in the model, including information relative to the testing of the scale reliability, dimensionality and validity. LISREL version 8.30 was employed to test the measurement model.

A Confirmatory Factor Analysis (CFA) was conducted on the FFP member samples to check the reliability and validity of the submodel of the research design. The CFA was run into each latent variable to test the performance of indicator variables in representing the manifest variables. The relationship between the latent constructs and the respective measured variables was called factorloadings. Each measured indicator variable has an error term (called error), which is the extent to which the latent factor does not explain the measured variable. Standard errors are estimates of the precision of each parameter estimate. Small standard errors correspond to good precision, and a large standard error to poor precision. The error magnitude depends on the units of measurement in the observed and/or latent variables and the magnitude of the parameter itself. $t$-values are often used practically, which are independent units of measurement. A t-value is the ratio between the parameter estimate and its standard error. Each hypothesis was considered supported at the 0.05 level of significant if its tvalue exceeded 1.96. These measures show how well the observed variable served as the measurement instrument of the latent variables. A Construct Reliability (CR) of more than 0.7 and a Variance Extracted (VE) of more than 0.5 were deemed to be an acceptable fit (Hair et al. 2010). For measuring the model, a ratio of the factor loadings to the standard error (lambda or loadings) of more than 0.5 was classified as reliable (Joreskog and Sorbom 1996).

The measurement model showed that the factor loadings for each construct were statistically significant (i.e. ranging from 0.65 to 1.0) and sufficiently high to demonstrate that the indicators and their underlying constructs were acceptable. Reliabilities ranged from 0.79 to 0.94 , and the variances extracted were above the threshold value from 0.63 to 0.83 . These results indicate that the measurement model is highly reliable and reasonably valid. The research ideas and hypotheses were operationally well represented by the questionnaire items. The results of the CFA for each constructs are presented in Appendix 3.

\section{Structural Model Assessment}

The structural equation model specifies the causal relationship among the latent variables and describes the causal effects and the amount of unexplained variances. The structural equation modeling method used in this research was LISREL version 8.30. The structural equation model was employed to test the structural base model and the hypothesized relationships among various constructs in the conceptual model of relational worth.

Due to the number of constructs in this study, two separate confirmatory factor models were run to test the hypotheses by measuring first order factors. The first CFA included all the constructs except relational worth. The second CFA included all the relationship quality factors and the relational worth dimension.

\section{Correlation Analysis}

Correlation analysis was done to check the correlation value between each variable. The correlations between the constructs are 
Table 2. Correlation Matrix

\begin{tabular}{|c|c|c|c|c|c|c|c|c|c|c|c|c|}
\hline & SR & ER & CRP & $\mathrm{AC}$ & NC & $\mathrm{CC}$ & STF & WOM & IM & OP & ACQ & HON \\
\hline SR & 1.0 & & & & & & & & & & & \\
\hline ER & 0.78 & 1.0 & & & & & & & & & & \\
\hline CRP & 0.78 & 0.83 & 1.0 & & & & & & & & & \\
\hline $\mathrm{AC}$ & 0.71 & 0.61 & 0.76 & 1.0 & & & & & & & & \\
\hline $\mathrm{NC}$ & 0.64 & 0.55 & 0.68 & 0.88 & 1.0 & & & & & & & \\
\hline CC & 0.60 & 0.51 & 0.59 & 0.63 & 0.65 & 1.0 & & & & & & \\
\hline STF & 0.77 & 0.60 & 0.74 & 0.76 & 0.68 & 0.58 & 1.0 & & & & & \\
\hline WOM & 0.71 & 0.56 & 0.68 & 0.78 & 0.65 & 0.53 & 0.97 & 1.0 & & & & \\
\hline IM & 0.65 & 0.60 & 0.63 & 0.67 & 0.81 & 0.54 & 0.68 & 0.59 & 1.0 & & & \\
\hline OP & 0.47 & 0.42 & 0.61 & 0.59 & 0.57 & 0.69 & 0.63 & 0.67 & 0.39 & 1.0 & & \\
\hline ACQ & 0.56 & 0.57 & 0.72 & 0.65 & 0.74 & 0.62 & 0,73 & 0.69 & 0.70 & 0.91 & 1.0 & \\
\hline $\mathrm{HON}$ & 0.51 & 0.50 & 0.58 & 0.55 & 0.51 & 0.52 & 0.59 & 0.54 & 0.46 & 0.74 & 0.82 & 1.0 \\
\hline
\end{tabular}

presented in Table 2. This includes the latent independent (exogenous) variables and latent dependent (endogenous) variables. As shown from the illustrated table, all parameters were significant at the 0.05 level.

\section{The Relationship between Relational Benefit and Relationship Quality}

The first measurement model (Chisquare $=456.63$, d.f. $=190)$ demonstrated a good fit with indices within the designated cutoff (RMSEA $=0.057$, GFI $=0.99$, AGFI $=$ 0.98, NFI=0.98, NNFI $=0.99, \mathrm{CFI}=0.99$ ).

The result partially supports the hypothesized predictions. Social reward had a positive effect on perceived affective commitment $(\beta=0.54)$ but economic reward was unrelated to affective commitment. Social reward was also positively related to continu- ance commitment $(\beta=0.62)$ and satisfaction $(\beta=0.65)$, while economic reward was negatively related to continuance commitment $(\beta=-0.12)$ and satisfaction $(\beta=-0.063)$. The reward policy positively influenced affective and continuance commitments. Hence, a perceived reward policy has a positive effect on customer commitment.

The study finds that the social reward benefit of a frequent flyer program had a positive effect on developing the relationship quality from both the aspect of customer commitment, and satisfaction as well. The $\beta \mathrm{s}$ show all positive numbers. The previous study by Melancon et al. 2011 whom examined a non-accumulated and paid reward program showed a different result. Their research predicted that the social reward benefit was negatively related to continuance commit- 
Table 3. Result of Hypotheses $\mathbf{H}_{1}-\mathbf{H}_{8}$ Testing

\begin{tabular}{llcccc}
\hline $\begin{array}{l}\text { Hypo- } \\
\text { theses }\end{array}$ & Relationship To Be Tested & $\begin{array}{c}\text { Hypothe- } \\
\text { sized } \\
\text { Direction }\end{array}$ & $\begin{array}{c}\text { Standard- } \\
\text { ized Beta } \\
\text { Coefficient }\end{array}$ & t-value & Remark \\
\hline $\mathrm{H}_{1}$ & Social Rewards $\rightarrow$ Affective Commitment & + & 0.54 & 15.51 & supported \\
$\mathrm{H}_{2}$ & Economic Rewards $\rightarrow$ Affective Commitment & - & -0.02 & -0.73 not supported \\
$\mathrm{H}_{3}$ & Social Rewards $\rightarrow$ Continuance Commitment & - & 0.62 & 11.41 & supported \\
$\mathrm{H}_{4}$ & Economic Rewards $\rightarrow$ Continuance Commitment & + & -0.12 & -2.96 & supported \\
$\mathrm{H}_{5}$ & Social Rewards $\rightarrow$ Satisfaction & + & 0.65 & 15.75 & supported \\
$\mathrm{H}_{6}$ & Economic Rewards $\rightarrow$ Satisfaction & + & -0.06 & -2.31 & supported \\
$\mathrm{H}_{7}$ & Controlling Reward Policy $\rightarrow$ Affective Commitment & - & 0.40 & 10.02 & supported \\
$\mathrm{H}_{8}$ & Controlling Reward Policy $\rightarrow$ Continuance Commitment & + & 0.40 & 6.10 & supported \\
\hline
\end{tabular}

Fit indices: Chi-square $=456.63$, d.f. $=190, \mathrm{CFI}=0.99, \mathrm{GFI}=0.99, \mathrm{NFI}=0.98, \mathrm{p}$-value $=0.00000, \mathrm{RMSEA}=0.057$

ment whereas their results showed that the social reward was not related to continuance commitment.

This study finds that the social reward benefit was significantly positive in relation to continuance commitment. This finding implies that the social rewards of a FFP play an important role for the members in engaging and strengthening their relationship with the airline, by means of emotional bonds (affective commitment), feelings of obligation (normative commitment) and also an intention to maintain their current level of benefits (continuance commitment). The social benefit of a FFP by means of special privileges, making the consumer feel like a special customer, personal recognition, customized treatments and priority reservation lists given to members, relative to the average passenger, significantly develops emotional bonds among the members to the airline without involving high costs.
The economic reward of a FFP did not have an effect on developing affective bonds with members for long-term relationships. Financial benefits by means of award-tickets, the upgrading of tickets and other nonair redemption transactions insignificantly influence the emotional bonds of the members with the airline. The study also suggested that respondents can be extrinsically motivated by the airline if it offers some investment-based reward to them. The economic reward is also significantly related to member's satisfaction. It is indicated that the benefits of award-tickets, upgrading tickets and other non-air redemption transactions have not yet influenced the members to engage with the airline through feeling of calculative commitment and/or satisfaction. This result implies that economic rewards are not yet considered by the members to support their continuance commitment and satisfaction. 
The redemption and earning reward policy governed by the airline had strengthened the emotional and investment-based bond with its customers. This suggested that the FFP members considered the rewards offered are flexible (no limitation) to them getting the benefit, because the airline placed few limitations on them acquiring their benefit, and the benefit is easily redeemable. On the contrary, past research on reward redemption (Melancon et al. 2011) found that the reward policy had a negative effect in building the emotional-based bond (affective commitment) and also the investment-based bond (continuance commitment). One reason for this opposite result might be due to the difference in the type of reward program examined in this research. Melancon et al. (2011) studied a specific paid and non-accumulated reward program, which is similar to many coupon reward schemes, while this research examine a non-paid and accumulated reward program. The later program involves customer effort to accrue the reward, for instance by accumulating a certain level of mileage over time before being awarded the reward. The fact that the reward was obtained through their exertions might bind a customer to the organization when he must abide by a certain policy in earning/redeeming the rewards. This behavior aligns with the CET literature in which customers feel they have more freedom in their autonomy or competence. The policy may increase customer commitment through influencing perceived autonomy or competence. When the informational dimensions of a reward are more salient, the reward will enhance the intrinsic motivation (Tietje 2002).

\section{The Relationship between Relationship Quality and Relational Worth}

This study is among the first to examine the impact of the relationship quality to relational worth by using a first degree measurement. Previous studies analyzed the relational worth by using a second degree measurement (Melancon et al. 2011).

The model was modified by taking honesty out of it, as this construct was not supporting the model. One of the reasons might be due to the relationship between members and the associated airline is considered to be a mutual relationship, in which no party is highly dependent on the other. Honesty measured opportunistic behavior which is likely to be found if the relationship is not a mutual one (Joshi and Arnold 1997). The other reason might be seemingly related to the respondent's culture. The majority of respondents were Indonesians. The question concerning opportunistic behavior is unlikely to be answered candidly by a high-context culture such as Indonesian. High-context cultures have careful enculturation and the meaning of individual behavior and speech changes depending on the situation or context (Johansson J. 2009).

The model assessing the impact of the relationship quality to relational worth (Chisquare $=355.38$, d.f. $=225)$ demonstrated a good fit with indices within the designated cut-off (RMSEA $=0.037, \mathrm{GFI}=0.99$, $\mathrm{AGFI}=0.99, \mathrm{NFI}=0.99, \mathrm{NNFI}=1.00, \mathrm{CFI}=$ $1.00)$.

Hypothesis 9-24 predicted the impact of the relationship quality on relational worth of the customer. Affective and normative 
Table 4. Result of Hypotheses $\mathbf{H}_{\mathbf{9}}-\mathbf{H}_{24}$ Testing

\begin{tabular}{|c|c|c|c|c|c|}
\hline $\begin{array}{l}\text { Hypo- } \\
\text { theses }\end{array}$ & Relationship To Be Tested & $\begin{array}{l}\text { Hypothe- } \\
\text { sized } \\
\text { Direction }\end{array}$ & $\begin{array}{l}\text { Standard- } \\
\text { ized Beta } \\
\text { Coefficient }\end{array}$ & $\mathrm{t}$-value & Remark \\
\hline $\mathrm{H}_{9}$ & Affective Commitment $\rightarrow$ WOM & + & 0.25 & 8.22 & Supported \\
\hline $\mathrm{H}_{10}$ & Affective Commitment $\rightarrow$ Immunity & + & 0.20 & 7.27 & Supported \\
\hline $\mathrm{H}_{11}$ & Affective Commitment $\rightarrow$ Openness & + & 0.22 & 7.45 & Supported \\
\hline $\mathrm{H}_{12}$ & Affective Commitment $\rightarrow$ Acquiescence & + & 0.19 & 6.73 & Supported \\
\hline $\mathrm{H}_{13}$ & Normative Commitment $\rightarrow \mathrm{WOM}$ & + & 0.18 & 2.78 & Supported \\
\hline $\mathrm{H}_{14}$ & Normative Commitment $\rightarrow$ Immunity & + & 0.62 & 11.35 & Supported \\
\hline $\mathrm{H}_{15}$ & Normative Commitment $\rightarrow$ Openness & + & 0.24 & 4.14 & Supported \\
\hline $\mathrm{H}_{16}$ & Normative Commitment $\rightarrow$ Acquiescence & + & 0.44 & 7.79 & Supported \\
\hline $\mathrm{H}_{17}$ & Continuance Commitment $\rightarrow \mathrm{WOM}$ & - & -0.14 & -1.39 & not supported \\
\hline $\mathrm{H}_{18}$ & Continuance Commitment $\rightarrow$ Immunity & - & 0.02 & 0.24 & not supported \\
\hline $\mathrm{H}_{19}$ & Continuance Commitment $\rightarrow$ Openness & - & 0.04 & 0.43 & not supported \\
\hline $\mathrm{H}_{20}$ & Continuance Commitment $\rightarrow$ Acquiescence & - & -0.02 & -0.20 & not supported \\
\hline $\mathrm{H}_{21}$ & Satisfaction $\rightarrow$ WOM & + & 0.81 & 12.51 & Supported \\
\hline $\mathrm{H}_{22}$ & Satisfaction $\rightarrow$ Immunity & + & 0.17 & 3.45 & Supported \\
\hline $\mathrm{H}_{23}$ & Satisfaction $\rightarrow$ Openness & + & 0.42 & 8.06 & Supported \\
\hline $\mathrm{H}_{24}$ & Satisfaction $\rightarrow$ Acquiescence & + & 0.38 & 7.27 & supported \\
\hline
\end{tabular}

Fit indices: Chi-square $=355.38$, d.f. $=225, \mathrm{CFI}=1.00, \mathrm{GFI}=0.99, \mathrm{NFI}=0.99, \mathrm{p}$-value $=0.00000$, RMSEA $=0.037$

commitments and satisfaction will have a positive influence on WOM, immunity, openness, and acquiescence, while continuance commitment will have an opposite influence. The result fully supports these predictions. Affective commitment had a positive effect on WOM $(\beta=0.25)$, immunity $(\beta=0.2)$, openness $(\beta=0.22)$, and acquiescence $(\beta=$ $0.19)$. Normative is positively related to
WOM $(\beta=0.18)$, immunity (positive effect on $(\beta=0.62)$, openness $(\beta=0.24)$, and acquiescence $(\beta=0.44)$. Satisfaction had a positive effect on WOM $(\beta=0.81)$, immunity $(\beta=0.17)$, openness $(\beta=0.42)$, and acquiescence $(\beta=0.38)$. Therefore, $\mathrm{H}_{9}-\mathrm{H}_{16}$ and $\mathrm{H}_{21}$ $\mathrm{H}_{24}$ are supported. However, the continuance commitments were unrelated to relational worth. Therefore, $\mathrm{H}_{17-20}$ are not supported. 
The study found that emotionally and normatively engaged FFP members voluntarily took part in some of the airline's duties by:

- spreading a positive word-of-mouth, taking on some of the promotional responsibilities of the airline including influencing family members and friends to use the airline (WOM);

- keep staying with the airline, showing no interest in better offers from competitors, and remaining with the airline even though they heard some negative information about the airline (immunity);

- providing feedback or suggestions on any experiences of imperfect service, offering suggestions for improvements and any information to help the airline to provide a better service (openness);

- adapting to necessary changes in their relationship with the airline, complying with requests or policies of the airline, and adjusting their travel to match the airline's schedule (acquiescence)

The study also finds that the normatively committed members also generate relational worth to the airline by means of WOM, immunity, openness and acquisition. This suggested that the FFP members also engaged in obligation-based attachments to the airline, in part by their social activities associated with WOM, immunity, openness, and acquiescence, which would be part of the airlines duties. Past researches have indicated diverse results, some research indicated a positive relationship between obligationbased commitments to relational worth, but the remaining found this to be to the contrary. Amongst those who found a negative relationship between the normative commitment and relational worth were Philips (2007) and Bansal et al. (2004). The reason for this opposite result might be due to the difference in the type of reward program examined by previous research, such as a paid and nonaccumulated reward program (Philips 2007). Our study examined a non-paid and accumulated reward program which involved customer effort to accrue the reward.

This study is among the first to consider the impact of satisfaction on relational worth. The results showed that members produced social behavior towards the airline when they felt satisfied with their relational exchanges. The feeling of satisfaction through the positive emotion of using the airline and the enjoyed interaction with the airline significantly generated relational worth, including WOM, immunity, openness, and acquiescence. Previous research have independently indicated the consequences of satisfaction on the willingness to inform others of their experiences with the firms (Reichheld and Sasser 1990; and Anderson 1998), willingness to stay in the current relationship (Morgan and Hunt 1994), willingness to recommend (Ping R. 1993; and Morgan and Hunt 1994), and acquiescence (Morgan and Hunt 1994). This study has proven that satisfied members also generate non-financial behaviors (WOM, immunity, openness and acquisition) that contribute to the value of the customer to the airline.

This finding implies that the social behavior of a customer to the organization is influenced by desire-based (affective commitment) and obligation-based (normative commitment) relationships as well as a feeling of satisfaction in the relationship. Referring to consumer behavior literature, when a consumer co-produces then they are helping with the service provision of the organization. The FFP members took part of the airline's mar- 
keting duties upon themselves by spreading a positive word-of-mouth, taking on some of the promotional responsibilities of the airline, including influencing their family members and friends to use the airline, keep using the airline, rejecting better offers from competitors, and still staying with the airline even though they heard some negative information about the airline, providing feedback or suggestion to the airline on its service, offering it suggestions forimprovement and any other information to help the airline to improve its operations, and adapting to any necessary changes in the relationship with the airline, complying with requests or policies of the airline, and arranging their travel to match the airlines schedule.

\section{Conclusion}

This research is the first to study the effects of the relational benefits on customer reaction to a paid and non-accumulated reward program which involves customer exertions to obtain the reward on offer. Moreover the introduction of variable satisfaction in the model of this study fills in the scientific gap of how the customer's efforts in obtaining the rewards could influence the relational outcome in terms of the relational worth between the customer and the organization.

This study led us to the following conclusions:

1. The perceived rewards had a significant impact on producing the non-financial value of customers by means of their social behaviors involving WOM, immunity, openness and acquisition, as follows:

- WOM: spreading a positive word-ofmouth, taking on some of the promotional responsibilities of the airline in- cluding influencing family members and friends to use the airline;

- Immunity: keep staying with the airline, not being interested in better offers from competitors, and staying with the airline even though they heard some negative information about the airline;

- Openness: providing feedback or suggestions on any experiences of poor service, offering suggestions for improvement and information to help the airline to improve its services;

- Acquiescence: adapting to necessary changes in the relationship with the airline, complying with requests or the airline's policy, adjusting their flights to match the airline schedule

2. Higher levels of commitment to and satisfaction with the airline developed from the social reward benefits than from the economic reward benefits.

Social reward benefits were characterized by the members feeling they were special customers, enjoying special privileges as members, having personal recognition and customized treatments, and receiving priority reservation status relative to the average passenger. Economic reward benefits included flight award redemption (free tickets and/or upgrades) and nonflight mileage redemption (hotel, shopping, donation, or travel package).

3. Informational (flexible) reward policy enhanced the influence of perceived rewards to the customer's commitment. Informational reward policy makes the FFP members feel they have flexibility (no limitation) in getting the members' benefits, they perceive few limitations in the airline's rules in acquiring the member's benefits, and such benefits are easy to redeem. 
Moreover, the involvement of the member enhances the influence of perceived rewards in a flexible policy on customer commitment. A highly involved customer would prioritize the airline in choosing a flight, actively visiting the FFP website to get new information or check mileage balances, and always using their membership in related transactions.

The study has taken steps to break down and understand the customer's behavior to a reward program offered through the frequent flyer programs in the airline industry. This research offers several interestinginsights into how a FFP should be managed to create a lasting and mutually beneficial relationship between both the customer and the airline.

\section{Limitations}

This research provides several findings on how reward programs may influence a customer's social behavior with an organization. However, the research does have some limitations, as discussed below.

The study only covered the respondents from one single FFP community (the FFP of the associated airline) in a specific context of a country (Indonesia). The constraint of access to other FFPs was the main factor for us being unable to examine the influence of reward benefit in a more general context. Research with access to actual FFP data from an airline is still uncommon (McCaughey and Behrens 2011).

The results might not be generalized either for another type of reward program or for other countries. Future research in various FFP programs is needed to determine how the influences of reward benefit customer valuation more accurately.
Moreover, the study is not capturing the effect of strategic alliances (multi-lateral alliance/MLA) amongst the airlines yet. Even though MLA gives substantial benefits to airlines but merging the individual FFPs in an alliance seems uncertain as it will depend on the homogeneous size of the program, the information technology \& databases settings, and also the flexibility to change a FFP to adapt to the other partners (Gudmundsson et al. 2002). A future study capturing the effect of MLA would be contributing to the body of knowledge of about this program.

\section{Managerial Implication}

This social reward benefit is not costly but can significantly strengthen customer commitment and satisfaction. It is suggested to airline management that they increase the level of social rewards. This social reward involves non-material rewards including personal recognition, special attention to, or treatment of its members, and giving them a high status relative to the average customer (Hennig-Thurau et al. 2000). Offering social rewards to the customer in exchange for repeat patronage results in intrinsically and extrinsically motivated customers and satisfied customers.

The social reward benefits are not only less costly to the organization, but can also be more easily generated by the organization than economic rewards. Also social rewards have a better long-term impact in terms of the relationship quality between consumer and organization. The goal would be for an airline to offer the highest level of social rewards possible to its customers as its offensive business strategy to enhance their long term loyalty and consumer value. Economic 
rewards could be offered at the lowest level if the airline was considering a defensive strategy such as during times of tight competition because it is difficult to eliminate once offered.

The nature of FFP reward programs where customers accrue points to earn the rewards had a positive effect on the relationship between the flexible type reward policy and customers' commitment and satisfaction levels. As a managerial recommendation, the goal would be for airline to set the reward policy for the easiness and flexibility of its FFP members to get the rewards. The associated FFP issues with the difficulty and restriction of the redemption policy could be exempted by means of clear and transparent rules communicated to customer and also offering reward benefits attractive to the customer. On the scope of this study, the flightbased benefits (award-ticket and ticket upgrades) are the most preferred rewards for the FFP members.

Satisfied customers generate more socially valuable behavior by means of WOM and openness than an individual with primary affective or normative commitment. Norma- tively committed consumers are producing higher levels of immunity and acquiescence than individuals with primary affective commitment. Therefore, the level of relational worth outcome would be governed by the nature of relational benefits and the quality of the relationship. As a managerial recommendation, the goal would be for airline to align the targeted outcome of consumers' social behavior with the nature of the reward benefits offered through the relational program, depending on the business strategy of the airline.

\section{Future Research}

Future research might explore these hypotheses in alternate contexts of non-paid and accumulated loyalty programs (ie department stores/automobile products/grocery stores/commuter-line or trains/cosmetics/ beauty products/etc) and loyalty programs in other geographic areas.

Further research into the effects of multi-lateral alliance on the same program would also be interesting.

\section{References}

Allen, N. J., and J. P. Meyer. 1990. The measurement and antecedents of affective, continuance, and normative commitment to the organization. Journal of Occupational Psychology 63: 1-18.

Allen, N. J., and J. P. Meyer. A three-component conceptualization of organization commitment. Journal of Occupational Psychology 1 (1): 61-89.

Anderson, E. W., and M. W. Sullivan. 1993. The antecedents and consequences of customer satisfaction for firms. Marketing Science 12 (2): 125-143.

Anderson, E. W. 1998. Customer satisfaction and word-of-mouth. Journal of Service Research 1 (1): 5-17.

Anderson, J. C., and D. W. Gerbing. 1988. Structural equation modeling in practice: A review and recommended two step approach. Psychological Bulletin 103: 411-423.

Bansal, H. S., P. G. Irving, and S. F. Taylor. 2004. A three component model of customer commitment to service providers. Journal of the Academy of Marketing Science 32 (3): 234-250. 
Barnes, J. 1994. The issue of establishing relationships with customers in service companies: When are relationships feasible and what form should they take. Working Paper. Memorial University of Newfoundland.

Bendapudi, N., and L. Berry. 1997. Customers' motivations for maintaining relationships with service providers. Journal of Retailing 73 (1): $15-37$.

Berry, L. 1995. Relationship marketing of services -Growing interest, emerging perspective. Journal of Academy of Marketing Science 23: 236 - 245.

Bolton, R. N., K. N. Lemon, and P. C. Verhoef. 2004. The theoretical underpinnings of customer asset management: A framework and propositions for future research. Journal of the Academy of Marketing Science 32 (3): 271-292.

Bowen, J., and S. Shoemaker. 2003. Development of taxonomy on services to gain strategic marketing insights loyalty: A strategic commitment. Cornell Hotel and Restaurant Administration Quarterly 44 (18): 431-469

Caruana, A. 2002. Service loyalty: The effects of service quality and the Mediating role of customer satisfaction. European Journal of Marketing 36 (7/8): 811-828.

Deci, E. L., and R. M. Ryan. 1985. Intrinsic Motivation and Self-Determination in Human Behavior. New York: Plenum.

Dowling, G., and M. Uncles. 1997. Do customer loyalty program really work? Sloan Management Review 38 (4): 71-82.

Finn, A. 2005. Reassessing the foundations of customer delight. Journal of Service Research 8: 103-116

Fornell, C. 1992. A national customer satisfaction barometer: The Swedish experience. Journal of Marketing 56: 6-21.

Fullerton, G. 2003. When does commitment lead to loyalty. Journal of Service Research 5 (4): 333-344.

Geykens, I., J. B. Steenkamp, L. K. Scheer, and N. Kumar. 1996. The effects on trust and interdependence on relationship commitment. A trans-atlantic study. International Journal of Research Marketing 13 (4): 303-317.

Gremler, D., and K. Gwinner. 2000. Customer-employee rapport in service relationships. Journal of Service Research 3: 82-104.

Gruen, T. W., J. O. Summers, and F. Acito. 2000. Relationship marketing activities, commitment, and membership behaviors in professional associations. Journal of Marketing 64 (3): 34-49.

Gudmundsson, S. V., E. R. de Boer, and C. Lechner. 2002. Integrating frequent flyer programs in multilateral airline alliances. Journal of Air Transport Management 8: 409-417.

Gwinner, K. P., D. D. Gremler, and M. J. Bitner. 1998. Relational benefits in services industries: The customer's perspective. Journal of Academy o Marketing Science 26 (2): 101- 114.

Hair, J. F., W. C. Black, B. J. Babin, and R. E. Anderson. 2010. Multivariate Data Analysis (7th ed.). New Jersey (US): Prentice Hall.

Hallowell, R. 1996. The relationship of customer satisfaction, customer loyalty and profitability: An empirical study. International Journal of Service Industry Management 7: 27-42.

Harison-Walker, L. 2001. The measurement of word-of-mouth communication and an investigation of service quality and customer commitment as potential antecedents. Journal of Service Research 4 (1): $60-75$. 
Heide, J. B., and G. John. 1992. Do norms mater in marketing relationships? Journal of Marketing 56 (2): $32-44$.

Hennig-Thurau, T., K. Gwinner, and D. D. Gremler. 2002. Understanding relationship marketing outcomes. Journal of the Service Research 4 (3): 230- 247.

Hennig-Thurau, T., and A. Klee. 1997. The impact of customer satisfaction and relationship quality on customer retention: A critical reassessment and model development. Journal of Psychology and Marketing 14: 737 - 764.

Hess, R. L., S. Ganesan, and N. M. Klein. 2003. Service failure and recovery: The impact of relationship factors on customer satisfaction. Journal of Academy of Marketing Science 31 (2): 127 - 144

Hirschman. 1970. Exit, Voice, and Loyalty. Cambridge, Massachusett, and London: Havard University Press.

Hogan, J., K. N. Lemon, and B. Libai. 2003. What is the true value of a lost customer? Journal of Service Research 5 (3): 196-208.

Hsieh, Y-H. 2007. Preferences of Business Travelers Regarding Frequent Flyer Program Benefit [thesis].San Jose (US): San Jose State University.

Ivens, B. S. 2004. How relevant are different forms of relational behavior? An empirical test based on Macneil's exchange framework. Journal of Business and Industrial Marketing 19 (4/5): 300-309

Iwasaki, Y., and M. E. Havitz. 1998. A path analytical model of relationship between involvement, psychological commitment and loyalty. Journal of Leisure Research 30 (2): 256-278.

Johansson, J. 2009. Global Marketing. Foreign Entry, Local Marketing and Global Management. (5 $5^{\text {th }}$ ed.). Singapore: McGraw-Hill.

Joreskog, K., Sorbom. 1996. Lisrel 8: User's Reference Guide. Chicago: Scientific Software International.

Joshi, A. W., and S. J. Arnold. 1997. The impact of buyer dependence on buyer opportunism in buyersupplier relationships: the moderating role of relational norms. Journal of Psychology and Marketing 14 (8): 823-845.

Krejcie, R. V., and D. W. Morgan. 1970. Determining sample size for research activities. Educational and Psychological Measurement 30: 607-610.

Liu, M. T., and J. L. Brock. 2008. Redemption behavior for credit card eeward programs in China. International Journal of Bank Marketing 27: 150-166

McCaughey, N. C., and C. Behrens. 2011. Paying for status? The effect of frequent flier program member status on air fare choice. Working Paper. Department of Economics, Monash University.

Melancon, J. P., S. M. Noble, and C. H. Noble. 2011. Managing rewards to enhance relational worth. Journal of Academy Marketing Science 39: 341-362.

Meyer, J., and J. Allen. 1991. A three-component conceptualization of organization commitment. Journal of Human Resource Management Review 1 (1): 61-89.

Meyer, J., D. Stanley, L. Herscovitch, and L. Topolnytsky. 2002. Affective, continuance, and normative commitment to the organization: A meta-analysis of antecedents, correlates, and consequences. Journal of Vocational Behavior 61: 20-52.

Moorman, C., G. Zaltman, and R. Despande. 1992. Relationships between providers and users of marketing research: the nature of trust within and between organizations. Journal of Marketing Research 10: 404-409. 
Morais, D. 2000. Reconceptualization of loyalty under a resource investment perspective: A study of group leaders in the leisure service industry. Dissertation. Clemson University.

Morgan, R., and S. Hunt. 1994. The commitment-trust theory of relationship marketing. Journal of Marketing 58: 20-38.

O'Connell, J. F. 2009. Frequent flyer programs. Working Paper. Presented to Garuda Indonesia in December 2009.

Oliver, R. L. 1980. A cognitive model of the antecedents and consequences of satisfaction decisions. Journal of Marketing Research 17: 46-49.

Phillips, J. 2007. Relational program effectiveness: The impact of reward type and policy on customer commitment and relational worth. Dissertation. The University of Mississippi.

Ping, R. 1993. The effect of satisfaction and Structural constraints on retailer exiting, voice, loyalty, opportunism, and neglect. Journal of Retailing 69 (3): 320-352.

Price, L., and E. Arnould. 1999. Commercial frienships: Service providers-client relationships in context. Journal of interactive marketing 63: 38-56.

Reichheld, F., and E. Sasser. 1990. Zero defections: Quality comes to services. Harvard Business Review (September-October): 105-111.

Reinartz, J. W., and V. Kumar. 2000. On the profitability of long-life customers in a noncontractual setting: An empirical investigation and implications for marketing. Journal of Marketing 64 (4): 17-35.

Rust, R., V. Zeithaml, and K. N. Lemon. 2000. Driving Customer Equity: How Customer Lifetime Value Is Reshaping Corporate Strategy. New York: The Free Press

Scott, C. 1976. The effects of trial and incentives on repeat purchase behavior. Journal of Marketing Research 13: 263-269.

Sumarwan, U., A. Jauzi, A. Mulyana, B. N. Karno, P. K. Mawardi, and W. Nugroho. 2011. Riset Pemasaran Dan Konsumen. Panduan Riset dan Kajian (1 ${ }^{\text {st }}$ ed.). Bogor: IPB Press

Van Kenhove, P. 2003. The relationship between consumers' unethical behavior and customer loyalty in a retail environment. Journal of Business Ethics 44 (4): 261-278.

Weber, K. 2005. Travelers' perceptions of airline alliance benefits and performance. Journal of Air Transport Research 43: 257-265.

Wilson, D. T. 1995. An integrated model of buyer-seller relationships. Journal of the Academy of Marketing Science 23 (4): 335-345.

Yang, J., and A. Liu. 2003. Frequent flyer program: A case study of China airline's marketing initiative Dynasty flyer program. Journal of Tourism Management 24 (1): 587-595. 
Gadjah Mada International Journal of Business - May-August, Vol. 16,Na 2, 2014

\section{Appendix 1. Validity Test of Indicator Variables}

\begin{tabular}{|c|c|c|c|c|}
\hline \multicolumn{2}{|l|}{ Constructs } & \multicolumn{2}{|c|}{$\begin{array}{l}\text { VALIDITY using } \\
\text { Factor Analysis }\end{array}$} & \multirow{2}{*}{$\frac{\text { Remark }}{\text { VALID }}$} \\
\hline Social Reward Benefit & This membership makes me feel I am a special customer & $\begin{array}{l}\text { Validity } \\
\mathrm{N}\end{array}$ & $\begin{array}{c}0,861 \\
30\end{array}$ & \\
\hline & I get special privileges according to my FFP membership & $\begin{array}{l}\text { Validity } \\
\mathrm{N}\end{array}$ & $\begin{array}{c}0,942 \\
30\end{array}$ & VALID \\
\hline & I get special treatment or attention from the staff of the & Validity & 0,944 & VALID \\
\hline & Airline & $\mathrm{N}$ & 30 & \\
\hline & $\begin{array}{l}\text { I usually get high priority reservation when there is a } \\
\text { waiting list }\end{array}$ & $\begin{array}{l}\text { Validity } \\
\mathrm{N}\end{array}$ & $\begin{array}{c}0,707 \\
30\end{array}$ & VALID \\
\hline \multirow[t]{4}{*}{$\begin{array}{l}\text { Economic Reward } \\
\text { benefit }\end{array}$} & I get upgrading ticket by mileage redemption & $\begin{array}{l}\text { Validity } \\
\mathrm{N}\end{array}$ & $\begin{array}{c}0,905 \\
30\end{array}$ & VALID \\
\hline & I get free ticket by mileage redemption & $\begin{array}{l}\text { Validity } \\
\mathrm{N}\end{array}$ & $\begin{array}{c}0,913 \\
30\end{array}$ & VALID \\
\hline & I get benefits from FFP non-flight mileage redemption & Validity & 0,899 & VALID \\
\hline & $\begin{array}{l}\text { like hotel, buying goods on the Airline Shop, donation or } \\
\text { travel }\end{array}$ & $\mathrm{N}$ & 30 & \\
\hline \multirow[t]{4}{*}{ Reward Policy } & $\begin{array}{l}\text { GFF procedures give no limitation on my ability to use } \\
\text { the benefits }\end{array}$ & $\begin{array}{l}\text { Validity } \\
\mathrm{N}\end{array}$ & $\begin{array}{c}0,885 \\
30\end{array}$ & VALID \\
\hline & $\begin{array}{l}\text { There is only few limitations placed on how I can use } \\
\text { my benefits }\end{array}$ & $\begin{array}{l}\text { Validity } \\
\mathrm{N}\end{array}$ & $\begin{array}{c}0,917 \\
30\end{array}$ & VALID \\
\hline & It is easy to redeem my benefits with this policy & Validity & 0,823 & VALID \\
\hline & & $\mathrm{N}$ & 30 & \\
\hline \multirow[t]{3}{*}{ Affective Commitment } & I feel emotionally attached to the Airline & $\begin{array}{l}\text { Validity } \\
\mathrm{N}\end{array}$ & $\begin{array}{c}0,914 \\
30\end{array}$ & VALID \\
\hline & I feel like part of the family with the Airline & $\begin{array}{l}\text { Validity } \\
\mathrm{N}\end{array}$ & $\begin{array}{c}0,975 \\
30\end{array}$ & VALID \\
\hline & I feel a strong sense of belonging to the Airline & $\begin{array}{l}\text { Validity } \\
\mathrm{N}\end{array}$ & $\begin{array}{l}0,950 \\
30\end{array}$ & VALID \\
\hline \multirow{7}{*}{$\begin{array}{l}\text { Normative } \\
\text { Commitment }\end{array}$} & I would feel guilty if I left the Airline now & Validity & 0,902 & VALID \\
\hline & & $\mathrm{N}$ & 30 & \\
\hline & I owe a great deal to the Airline & Validity & 0,915 & VALID \\
\hline & & $\mathrm{N}$ & 30 & \\
\hline & $\begin{array}{l}\text { I do not feel it would be right to leave the Airline, even if } \\
\text { it were to my advantage }\end{array}$ & Validity & $\begin{array}{l}0,932 \\
\mathrm{~N}\end{array}$ & $\begin{array}{l}\text { VALID } \\
30\end{array}$ \\
\hline & I feel a sense of obligation to remain a customer of the & Validity & 0,968 & VALID \\
\hline & Airline & $\mathrm{N}$ & 30 & \\
\hline Continuance & Another airline might not match the overall benefits & Validity & 0,875 & VALID \\
\hline \multirow[t]{3}{*}{ Commitment } & I have here & $\mathrm{N}$ & 30 & \\
\hline & It wouldn't cost me a lot to leave the Airline & Validity & 0,892 & VALID \\
\hline & & $\mathrm{N}$ & 30 & \\
\hline
\end{tabular}


Appendix 1. Validity Test of Indicator Variables (Continued)

\begin{tabular}{|c|c|c|c|c|}
\hline \multirow{2}{*}{$\begin{array}{l}\text { Constructs } \\
\text { Satisfaction }\end{array}$} & \multirow[b]{2}{*}{ My choice to use the Airline was a wise one } & \multicolumn{2}{|c|}{$\begin{array}{l}\text { VALIDITY using } \\
\text { Factor Analysis }\end{array}$} & \multirow{2}{*}{$\begin{array}{l}\text { Remark } \\
\text { VALID }\end{array}$} \\
\hline & & $\begin{array}{l}\text { Validity } \\
\mathrm{N}\end{array}$ & $\begin{array}{l}0,925 \\
30\end{array}$ & \\
\hline & I am always delighted with the Airline & $\begin{array}{l}\text { Validity } \\
\mathrm{N}\end{array}$ & $\begin{array}{c}0,939 \\
30\end{array}$ & VALID \\
\hline & Overall, I am satisfied with the Airline & $\begin{array}{l}\text { Validity } \\
\mathrm{N}\end{array}$ & $\begin{array}{c}0,916 \\
30\end{array}$ & VALID \\
\hline \multirow[t]{3}{*}{ WOM } & I try to get my friends and family to use the Airline & $\begin{array}{l}\text { Validity } \\
\mathrm{N}\end{array}$ & $\begin{array}{c}0,932 \\
30\end{array}$ & VALID \\
\hline & I often tell others good things about the Airline & $\begin{array}{l}\text { Validity } \\
\mathrm{N}\end{array}$ & $\begin{array}{c}0,935 \\
30\end{array}$ & VALID \\
\hline & $\begin{array}{l}\text { I would defend the Airline to others if I heard someone } \\
\text { speaking poorly about the Airline }\end{array}$ & $\begin{array}{l}\text { Validity } \\
\mathrm{N}\end{array}$ & $\begin{array}{c}0,856 \\
30\end{array}$ & VALID \\
\hline \multirow[t]{3}{*}{ Immunity } & $\begin{array}{l}\text { I would not switch to other airline, even if it made me } \\
\text { a better offer }\end{array}$ & $\begin{array}{l}\text { Validity } \\
\mathrm{N}\end{array}$ & $\begin{array}{l}0,730 \\
30\end{array}$ & VALID \\
\hline & $\begin{array}{l}\text { Even if I heard some negative information about the } \\
\text { Airline, I would not switch to other airline }\end{array}$ & $\begin{array}{l}\text { Validity } \\
\mathrm{N}\end{array}$ & $\begin{array}{c}0,956 \\
30\end{array}$ & VALID \\
\hline & I am not interested in offers from other airline & $\begin{array}{l}\text { Validity } \\
\mathrm{N}\end{array}$ & $\begin{array}{l}0,910 \\
30\end{array}$ & VALID \\
\hline \multirow[t]{3}{*}{ Openness } & $\begin{array}{l}\text { I feel comfortable telling the Airline when I think } \\
\text { something needs improvement }\end{array}$ & $\begin{array}{l}\text { Validity } \\
\mathrm{N}\end{array}$ & $\begin{array}{c}0,913 \\
30\end{array}$ & VALID \\
\hline & $\begin{array}{l}\text { I will occasionally suggest improvements to the Airline if } \\
\text { there is a problem with my service }\end{array}$ & $\begin{array}{l}\text { Validity } \\
\mathrm{N}\end{array}$ & $\begin{array}{c}0,911 \\
30\end{array}$ & VALID \\
\hline & I am willing to provide information to help the Airline & $\begin{array}{l}\text { Validity } \\
\mathrm{N}\end{array}$ & $\begin{array}{c}0,934 \\
30\end{array}$ & VALID \\
\hline \multirow[t]{3}{*}{ Acquiescence } & $\begin{array}{l}\text { I try hard to comply with any requests the Airline } \\
\text { makes of me }\end{array}$ & $\begin{array}{l}\text { Validity } \\
\mathrm{N}\end{array}$ & $\begin{array}{l}0,928 \\
30\end{array}$ & VALID \\
\hline & $\begin{array}{l}\text { I try to be understanding if the organization must make } \\
\text { a change in an agreement we've made }\end{array}$ & $\begin{array}{l}\text { Validity } \\
\mathrm{N}\end{array}$ & $\begin{array}{l}0,948 \\
30\end{array}$ & VALID \\
\hline & I will adjust my trip to the Airline schedule & $\begin{array}{l}\text { Validity } \\
\mathrm{N}\end{array}$ & $\begin{array}{c}0,942 \\
30\end{array}$ & VALID \\
\hline \multirow[t]{3}{*}{ Honesty } & $\begin{array}{l}\text { I feel that I owe it to the Airline to be completely honest } \\
\text { in all our dealings }\end{array}$ & $\begin{array}{l}\text { Validity } \\
\mathrm{N}\end{array}$ & $\begin{array}{c}0,795 \\
30\end{array}$ & VALID \\
\hline & $\begin{array}{l}\text { I would feel guilty if I took advantage of the Airline if } \\
\text { it is not my rights }\end{array}$ & $\begin{array}{l}\text { Validity } \\
\mathrm{N}\end{array}$ & $\begin{array}{c}0,923 \\
30\end{array}$ & VALID \\
\hline & $\begin{array}{l}\text { I woud never want to take advantage of the Airline if } \\
\text { it is not my rights }\end{array}$ & $\begin{array}{l}\text { Validity } \\
\mathrm{N}\end{array}$ & $\begin{array}{c}0,845 \\
30\end{array}$ & VALID \\
\hline
\end{tabular}




\section{Appendix 2. Reliability Statistics}

Cronbach's alpha $=0.9754$

\begin{tabular}{|c|c|c|c|c|}
\hline Item-Total Statistics & $\begin{array}{l}\text { Scale Mean } \\
\text { if Item } \\
\text { Deleted }\end{array}$ & $\begin{array}{l}\text { Scale Variance } \\
\text { if Item } \\
\text { Deleted }\end{array}$ & $\begin{array}{l}\text { Corrected } \\
\text { Item-Total } \\
\text { Correlation }\end{array}$ & $\begin{array}{l}\text { Cronbach's } \\
\text { alpha if Item } \\
\text { Deleted }\end{array}$ \\
\hline $\begin{array}{l}\text { This membership makes me feel I am a } \\
\text { special customer }\end{array}$ & 182.333 & 984.506 & 0.748 & 0.975 \\
\hline $\begin{array}{l}\text { I get special privileges according to my FFP } \\
\text { membership }\end{array}$ & 182.667 & 974.161 & 0.835 & 0.974 \\
\hline $\begin{array}{l}\text { I get special treatment or attention from } \\
\text { the staff of the Airline }\end{array}$ & 182.8 & 986.303 & 0.795 & 0.974 \\
\hline $\begin{array}{l}\text { I usually get high priority reservation when } \\
\text { there is awaiting list }\end{array}$ & 182.867 & 1000.947 & 0.608 & 0.975 \\
\hline $\begin{array}{l}\text { I get upgrading ticket by mileage } \\
\text { redemption }\end{array}$ & 182.667 & 992.368 & 0.683 & 0.975 \\
\hline I get free ticket by mileage redemption & 182.8 & 993.062 & 0.765 & 0.975 \\
\hline $\begin{array}{l}\text { I get benefits from FFP non-flight mileage } \\
\text { redemption like hotel, buying goods on } \\
\text { the Airline Shop, donation ortravel package }\end{array}$ & 183.067 & 975.444 & 0.808 & 0.974 \\
\hline $\begin{array}{l}\text { GFF procedures give no limitation on my } \\
\text { ability to use the benefits }\end{array}$ & 182.867 & 982.947 & 0.703 & 0.975 \\
\hline $\begin{array}{l}\text { There is only few limitations placed on } \\
\text { how I can use my benefits }\end{array}$ & 183.033 & 987.551 & 0.713 & 0.975 \\
\hline $\begin{array}{l}\text { It is easy to redeem my benefits with this } \\
\text { policy }\end{array}$ & 182.467 & 990.809 & 0.783 & 0.974 \\
\hline I feel emotionally attached to the Airline & 182.433 & 975.978 & 0.808 & 0.974 \\
\hline I feel like part of the family with the Airline & 182.467 & 971.499 & 0.827 & 0.974 \\
\hline $\begin{array}{l}\text { I feel a strong sense of belonging to the } \\
\text { Airline }\end{array}$ & 182.4 & 975.214 & 0.774 & 0.974 \\
\hline I would feel guilty if I left the Airline now & 182.5 & 973.845 & 0.846 & 0.974 \\
\hline I owe a great deal to the Airline & 182.733 & 968.685 & 0.853 & 0.974 \\
\hline $\begin{array}{l}\text { I do not feel it would be right to leave the } \\
\text { Airline, even if it were to my advantage }\end{array}$ & 182.7 & 977.528 & 0.828 & 0.974 \\
\hline $\begin{array}{l}\text { I feel a sense of obligation to remain a } \\
\text { customer of the Airline }\end{array}$ & 182.733 & 973.857 & 0.84 & 0.974 \\
\hline $\begin{array}{l}\text { Another airline might not match the overall } \\
\text { benefits I have here }\end{array}$ & 182.467 & 997.499 & 0.639 & 0.975 \\
\hline It wouldn't cost me a lot to leave the Airline & 182.9 & 1000.783 & 0.511 & 0.976 \\
\hline My choice to use the Airline was a wise one & 182.067 & 1000.892 & 0.792 & 0.975 \\
\hline I am always delighted with the Airline & 182.2 & 1004.855 & 0.712 & 0.975 \\
\hline
\end{tabular}


Appendix 2. Reliability Statistics (Continued)

\begin{tabular}{|c|c|c|c|c|}
\hline \multicolumn{5}{|l|}{ Cronbach's alpha $=0.9754$} \\
\hline Item-Total Statistics & $\begin{array}{l}\text { Scale Mean } \\
\text { if Item } \\
\text { Deleted }\end{array}$ & $\begin{array}{l}\text { Scale Variance } \\
\text { if Item } \\
\text { Deleted }\end{array}$ & $\begin{array}{l}\text { Corrected } \\
\text { Item-Total } \\
\text { Correlation }\end{array}$ & $\begin{array}{l}\text { Cronbach's } \\
\text { alph a if Item } \\
\text { Deleted } \\
\end{array}$ \\
\hline Overall, I am satisfied with the Airline & 181.933 & 1004.616 & 0.648 & 0.975 \\
\hline $\begin{array}{l}\text { I try to get my friends and family to use the } \\
\text { Airline }\end{array}$ & 182.033 & 1004.033 & 0.799 & 0.975 \\
\hline $\begin{array}{l}\text { I often tell others good things about the } \\
\text { Airline }\end{array}$ & 182 & 1006.621 & 0.692 & 0.975 \\
\hline $\begin{array}{l}\text { I would defend the Airline to others if } \\
\text { I heard someone speaking poorly about } \\
\text { the Airline }\end{array}$ & 182.333 & 1004.782 & 0.662 & 0.975 \\
\hline $\begin{array}{l}\text { I would not switch to other airline, even } \\
\text { if it made me a better offer }\end{array}$ & 182.333 & 1007.195 & 0.648 & 0.975 \\
\hline $\begin{array}{l}\text { Even if I heard some negative information } \\
\text { about the Airline, I would not switch to } \\
\text { other airline }\end{array}$ & 182.633 & 995.275 & 0.701 & 0.975 \\
\hline I am not interested in offers from other airline & 182.6 & 988.938 & 0.664 & 0.975 \\
\hline $\begin{array}{l}\text { I feel comfortable telling the Airline when } \\
\text { I think something needs improvement }\end{array}$ & 182.867 & 1002.533 & 0.522 & 0.975 \\
\hline $\begin{array}{l}\text { I will occasionally suggest improvements to } \\
\text { the Airline if there is a problem with my } \\
\text { service }\end{array}$ & 182.533 & 997.499 & 0.695 & 0.975 \\
\hline $\begin{array}{l}\text { I am willing to provide information to help } \\
\text { the Airline }\end{array}$ & 182.767 & 1000.323 & 0.627 & 0.975 \\
\hline $\begin{array}{l}\text { I try hard to comply with any requests } \\
\text { the Airline makes of me }\end{array}$ & 182.133 & 1011.913 & 0.579 & 0.975 \\
\hline $\begin{array}{l}\text { I try to be understanding if the organization } \\
\text { must make a change in an agreement we've } \\
\text { made }\end{array}$ & 182.133 & 1005.844 & 0.661 & 0.975 \\
\hline I will adjust my trip to the Airline schedule & 182.1 & 1003.817 & 0.684 & 0.975 \\
\hline $\begin{array}{l}\text { I feel that I owe it to the Airline to be } \\
\text { completely honest in all our dealings }\end{array}$ & 182.567 & 989.426 & 0.848 & 0.974 \\
\hline $\begin{array}{l}\text { I would feel guilty if I took advantage of } \\
\text { the Airline if it is not my rights }\end{array}$ & 182.4 & 1003.628 & 0.576 & 0.975 \\
\hline $\begin{array}{l}\text { I would never want to take advantage of the } \\
\text { Airline if it is not my rights }\end{array}$ & 182.133 & 1011.499 & 0.559 & 0.975 \\
\hline
\end{tabular}


Appendix 3. Measurement of Model Assessment

\begin{tabular}{|c|c|c|c|c|}
\hline Variables & CR & VE & Items & coadings \\
\hline \multirow[t]{5}{*}{ Social Reward Benefit (SR) } & \multirow[t]{5}{*}{0.91} & \multirow[t]{5}{*}{0.75} & \multicolumn{2}{|l|}{ My FFP memberships carry benefits that means... } \\
\hline & & & This membership makes me feel I am a special customer & 0.77 \\
\hline & & & I get special privileges according to my FFP membership & 0.80 \\
\hline & & & $\begin{array}{l}\text { I get special treatment or attention from the staff of the } \\
\text { Airline }\end{array}$ & 0.95 \\
\hline & & & $\begin{array}{l}\text { I usually get high priority reservation when there is a } \\
\text { waiting list }\end{array}$ & 0.85 \\
\hline \multirow[t]{4}{*}{ Economic Reward benefit (ER) } & \multirow[t]{4}{*}{0.92} & \multirow[t]{4}{*}{0.81} & \multicolumn{2}{|l|}{ My FFP memberships carry benefits that means... } \\
\hline & & & I get upgrading ticket by mileage redemption & 0.87 \\
\hline & & & I get free ticket by mileage redemption & 0.97 \\
\hline & & & $\begin{array}{l}\text { I get benefits from FFP non-flight mileage } \\
\text { redemption like hotel, buying goods on the Airline Shop, } \\
\text { donation or travel package }\end{array}$ & 0.83 \\
\hline \multirow[t]{3}{*}{ Controlling Reward Policy (CRP) } & \multirow[t]{3}{*}{0.82} & \multirow[t]{3}{*}{0.66} & $\begin{array}{l}\text { GFF procedures give no limitation on my ability to use } \\
\text { the benefits }\end{array}$ & 0.87 \\
\hline & & & $\begin{array}{l}\text { There is only few limitations placed on how I can use } \\
\text { my benefits }\end{array}$ & 0.77 \\
\hline & & & It is easy to redeem my benefits with this policy & 0.68 \\
\hline \multirow[t]{3}{*}{ Affective Commitment (AC) } & \multirow[t]{3}{*}{0.92} & \multirow[t]{3}{*}{0.81} & I feel emotionally attached to the Airline & 0.86 \\
\hline & & & I feel like part of the family with the Airline & 0.93 \\
\hline & & & I feel a strong sense of belonging to the Airline & 0.89 \\
\hline \multirow[t]{4}{*}{ Normative Commitment (NC) } & \multirow[t]{4}{*}{0.94} & \multirow[t]{4}{*}{0.82} & I would feel guilty if I left the Airline now & 0.87 \\
\hline & & & I owe a great deal to the Airline & 0.84 \\
\hline & & & $\begin{array}{l}\text { I do not feel it would be right to leave the Airline, } \\
\text { even if it were to my advantage }\end{array}$ & 0.97 \\
\hline & & & $\begin{array}{l}\text { I feel a sense of obligation to remain a customer } \\
\text { of the Airline }\end{array}$ & 0.91 \\
\hline \multirow[t]{2}{*}{ Continuance Commitment (CC) } & \multirow[t]{2}{*}{0.90} & \multirow[t]{2}{*}{0.88} & $\begin{array}{l}\text { Another airline might not match the overall benefits } \\
\text { I have here }\end{array}$ & 1.00 \\
\hline & & & It wouldn't cost me a lot to leave the Airline & 0.81 \\
\hline \multirow[t]{3}{*}{ Satisfaction (STF) } & \multirow[t]{3}{*}{0.92} & \multirow[t]{3}{*}{0.80} & My choice to use the Airline was a wise one & 0.81 \\
\hline & & & I am always delighted with the Airline & 0.96 \\
\hline & & & Overall, I am satisfied with the Airline & 0.90 \\
\hline \multirow[t]{3}{*}{ WOM } & \multirow[t]{3}{*}{0.90} & \multirow[t]{3}{*}{0.78} & I try to get my friends and family to use the Airline & 0.93 \\
\hline & & & I often tell others good things about the Airline & 0.97 \\
\hline & & & $\begin{array}{l}\text { I would defend the Airline to others if I heard } \\
\text { someone speaking poorly about the Airline }\end{array}$ & 0.69 \\
\hline
\end{tabular}




\section{Appendix 3. Measurement of Model Assessment (Continued)}

\begin{tabular}{|c|c|c|c|c|}
\hline Variables & CR & VE & Items & Loadings \\
\hline \multirow[t]{3}{*}{ Immunity (IM) } & 0.89 & 0.76 & $\begin{array}{l}\text { I would not switch to other airline, even if it made me } \\
\text { a better offer }\end{array}$ & 0.88 \\
\hline & & & $\begin{array}{l}\text { Even if I heard some negative information about } \\
\text { the Airline, I would not switch to other airline }\end{array}$ & 0.74 \\
\hline & & & I am not interested in offers from other airline & 0.92 \\
\hline \multirow[t]{3}{*}{ Openness (OP) } & 0.85 & 0.70 & $\begin{array}{l}\text { I feel comfortable telling the Airline when I think } \\
\text { something needs improvement }\end{array}$ & 0.74 \\
\hline & & & $\begin{array}{l}\text { I will occasionally suggest improvements to the Airline } \\
\text { if there is a problem with my service }\end{array}$ & 0.94 \\
\hline & & & I am willing to provide information to help the Airline & 0.72 \\
\hline \multirow[t]{3}{*}{ Acquiescence (ACQ) } & 0.79 & 0.63 & $\begin{array}{l}\text { I try hard to comply with any requests the Airline makes } \\
\text { of me }\end{array}$ & 0.74 \\
\hline & & & $\begin{array}{l}\text { I try to be understanding if the organization must make a } \\
\text { change in an agreement we've made }\end{array}$ & a 0.85 \\
\hline & & & I will adjust my trip to the Airline schedule & 0.65 \\
\hline \multirow[t]{3}{*}{ Honesty (HON) } & 0.90 & 0.77 & $\begin{array}{l}\text { I feel that I owe it to the Airline to be completely } \\
\text { honest in all our dealings }\end{array}$ & 0.72 \\
\hline & & & $\begin{array}{l}\text { I would feel guilty if I took advantage of the Airline if } \\
\text { it is not my rights }\end{array}$ & 1.00 \\
\hline & & & $\begin{array}{l}\text { I would never want to take advantage of the Airline if } \\
\text { it is not my rights }\end{array}$ & 0.85 \\
\hline
\end{tabular}


